\title{
Chinese Historiography
}

\author{
By Albert Feuerwerker*
}

Since the establishment of the People's Republic of China in 1949, a vast outpouring of historical writing-in books, periodicals, and the cultural pages of newspapers-has flowed from the research institutes and universities of Peking, Shanghal, and elsewhere. In spite of sometimes considerable difficulties in obtaining current publications from China, a significant part of this flood has reached the libraries of Japan, Europe, and America, where in recent years work on the history of China has seen a remarkable growth. It is inevitable that non-Chinese scholars of Chinese civilisation will have to take into account the new historiography emanating from Communist China.

To examine and evaluate historical writing in China under the Communist regime some thirty specialists on Chinese history from the United States, England, Europe, Japan, Australia, and Malaya met at Ditchley Park, Oxfordshire, from 6-12 September, 1964. The conference was sponsored by The China Quarterly. The plans for the discussions grew out of an earlier conference which that journal had sponsored on Chinese Communist Literature.

It was apparent from the papers and the lively discussions which they occasioned that the writing of history in China continues to occupy under the present regime, as under its predecessors over more than two millenia, a critical place among the preoccupations of the ruling strata. From its beginnings, the writing of history in China has been intimately associated with the politics of the Chinese state...as a justification for bold departures which, it was claimad, were merely restoring the "golden age" of the great sages of the past, as a means of legitimising the succession of one rul-

* Albert Feuerwerker acted as Chairman of the conference described in this article. He is Professor of History and Director of the Center for Chinese Studies, University of Michigan. $\mathrm{He}$ is the author of China's Early Industrialization: Sheng Hsuan-Huai (1844-1916) and Mandarine Enterprise and co-author of Chinese Communist Studies of Modern Chinese history. ing group to the throne of its predecessor, as a powerful weepon in the struggles of factions and cliques over the centuries. Like its predecessors the government of the People's Republic of China has been acutely aware of the political uses of history, and since coming to power in 1949 it has vigourously promoted the rewriting of the Chinese past.

The Chinese Communist reinterpretation of China's history has, in considerable part, been offered as propaganda designed to perpetuate support of the present regime among the Chinese people. But there is something more to it than this. Historical writing in China today, as viewed by her nation's leaders, represents a genuine attempt to find legitimisation in China's past for the developments of her most recent present. For the Confucian ideology of imperial China, the Communist government in Peking has, of course, substituted a still developing Maoist version of Marxism-Leninism as the touchstone for the assessment of the past. But it would be misleading to suppose that what was peculiarly Chinese, either in motivation or in substance, has been totally expunged from the historiography of China by the Communist revolution.

The conference discussions addressed themselves to three major questions :

1. What was the substantive value of Chinese historical writing since 1949 in the various fields in which the conference participants were interested? What new data or interpretations had been presented, and how should they be evaluated?

2. What are the main characteristics of historical theory, method, and the organisation of teaching and research in China today; and how do they differ from the past?

3. What connections were there between the content and form of post 1949 historical writing and the domestic policies and international relations of the Chinese Communist regime? What light does an analysis of Chinese Communist historiography throw on Chinese Communist society today? 
With respect to the first of these questions, the participants agreed that the picture was a mixed one. In spite of the tremendous outpouring of historical works since 1949, there were huge arears of the past which, for political and ideological reasons and because of limited trained manpower, the Chinese historians had barely touched. It was noted, for example, that until quite recently the overwhelming emphasis of historical research had been placed either on the pre-Han period or on the nineteenth and twentieth centuries. This left a 2000-year gap which was indiscriminately labelled "feudal" and which received relatively little attention. Even for those periods on which more work. had been done, the Chinese historians tended to restrict themselves to a limited number of topics more or less directly related to the problem of constructing a new past to replace the discarded Confucian-literati raiment : periodisation (e.g. when did the era of slavery end and that of feudalism begin ?), the interpretation of peasant rebellions, the formation of the Han nation, the nature of landholding in "feudal" China, the controversy over the origins of capitalism in China, and the role of "imperialism" in modern Chinese history. It was agreed that among the several subfields of history, work in archaeology was generally of a higher order of excellence and more free of political distortions than work done in other fields. Little new of interpretive value had resulted from recent treatments of China's traditional history, and a fortiori of modern Chinese history. But, especially in the modern field, the large-scale publication of generally well-edited source material was a boon to scholars of China everywhere.
On the second question, continuities and divergencies between traditional and Marxist-LeninistMaoist historiography were noted; and particular attention was given to the manner in which the Marxist materialist conception of history had taken on a special Maoist Chinese form which diverged considerably from classical Marxism. Probably because the information available is so inadequate, the conference participants generally felt that the discussions on the organisation of historical studies in China today, and the working conditions (material and ideological-political) of practising historians, were the least satisfactory.

With respect to the last question, the conference discussed the effects of the "Hundred Flowers" interlude and the subsequent anti-rightist campaign, upon historiography in China. A good deal of attention was paid to the growing nationalist flavour of Chinese historical work since about 1959, and this, it was felt, could be directly correlated with the widening Sino-Soviet rift. There was considerable discussion of what the effects of this nationalist turn would be upon the treatment of that part of the past which had once been rejected out of hand as "feudal". It appeared that some feudal despots, at least, were gradually being transformed into national heroes. This kind of reinterpretation, however, conceivably could be troublesome if carried 100 far, as it tends to undermine the "class viewpoint" so vigorously pushed in other connections by the Chinese Communist leadership.

The papers presented at the conference will be published by The China Quarterly in the course of the next year.

"The weapon is an important factor in war, but it is not the decisive factor. The decisive factor is man and not material. A comparison of strength means more than a comparison of military strength and economic strength. It is also a comparison of manpower resources and the hearts of the people. Military strength and economic strength have to be manned." (On Protracted War, Selected Works of Mao Tse-tung, Vol. 2, p. 459).

On the one hand, we must see that nuclear weapons and guided missiles are weapons of great power, and we must march in the direction of science and technology and exert our utmost effort to scale the peaks of science and technology and catch up with and surpass the most developed imperialist countries. On the other hand, we must see even more that no matter how powerful a new-type weapon may be, it will never change the truth that "the militia is the foundation of victory." While atom bombs are very powerful, spiritual atom bombs are a thousand times more so. By spiritual atom bombs, we mean the just nature of our war against aggression, the indignation of hundreds of millions of people, and their heroic and dogged fighting spirit..... With the support of the masses of the people, we are in the most superior position. We have now mastered material atom bombs, but the enemy wil! never be able to obtain spiritual atom bombs.

Liu Yun-Chen in Jen-min Jih-pao, November, 18, 1964. 